\title{
Kurumsal Sosyal Performansa Piyasa Tepkisi: BIST Örneği*
}

\author{
Sinem ATEŞ**
}

\section{ÖZET}

Bu çalışma ile şirketlerin kurumsal sosyal performanslarının hisse senedi fiyatları ile ölçülen finansal performanslarına yansiyıp yansımadı̆ğn tespit etmek hedeflenmistitir. Bu hedef doğrultusunda Borsa İstanbul'da işlem gören firmaların 2009-2017 ylllarına ait verileri, panel veri yöntemleri ile analiz edilmişstir. Ampirik analizler, şirket büyüklüğ̈̈, riski, karlllığı, sektörü gibi faktörler sabit tutulduğunda dahi kurumsal sosyal performans ile hisse senedi fiyatları arasinda pozitif ve anlamlı bir ilişki olduğunu göstermiştir. Kurumsal sosyal performansın alt boyutları için yapılan analizler, şirketlerin çevresel performansları haricinde sosyal ve yönetişsim performansları ile piyasa değerleri arasında pozitif ve anlamlı bir iliş̧kiye işaret etmektedir. Öte yandan çevresel performans ile hisse senedi fiyatları arasında anlamlı bir ilişki bulunamamıştır.

Anahtar Kelimeler: Kurumsal Sosyal Performans, Piyasa Değeri, Çevresel Performans, Sosyal Performans, Yönetişim Performansl

JEL Sinıflandırması: M41, M14, G14

\section{Market Reaction to Corporate Social Performance: Evidence from BIST}

\section{ABSTRACT}

Through this study, it is aimed to determine whether the corporate social performance of companies has an impact on financial performance measured by stock prices. In line with this target, the data of the companies listed in Borsa Istanbul for 2009-2017 were analyzed using panel data methods. Empirical analyses show that there is a positive and significant relationship between corporate social performance and stock prices, even when factors such as company size, risk, profitability, and industry are controlled. Analyses for the individual pillars of corporate social performance indicate a positive and significant relationship between market value and social and governance performances, except for environmental performance. On the other hand, no significant relationship was found between environmental performance and stock prices.

Keywords: Corporate Social Performance, Market Value, Environmental Performance, Social Performance, Governance Performance

Jel Classification: M41, M14, G14

\footnotetext{
* Makale Gönderim Tarihi: 18.11.2020, Makale Kabul Tarihi: 08.02.2021, Makale Türü: Nicel Araştırma

** Dr., Yalova Üniversitesi, İktisadi ve İdari Bilimler Fakültesi, sinem.ates@yalova.edu.tr, ORCID: 0000-00029999-3799.
} 


\section{GİRiş}

Şirketlerin yatırımcılarının yanı sıra diğer tüm paydaşlarına olan sorumluluklarının önem kazanması ve sorgulanmaya başlanması ile birlikte "kurumsal sosyal sorumluluk (KSS)" ve "kurumsal sosyal performans (KSP)" kavramları öne çıkmıştır. Bu kavramlar için literatürde genel geçer tek bir tanımlama olmayıp farklı tanımlamalar mevcuttur.

Davis and Bloomstrom'a (1975: 6) göre, yönetimsel bir sorumluluk olan KSS, şirketin kendi çıkarlarını gözetirken aynı zamanda toplumun da refahını gözetmek, korumak ve geliştirmek için çabalamasıdır. Carroll (1979) şirketin yasal sorumluluklarını ekonomik, yasal, etik ve gönüllü sorumluluklar olarak sınıflandırırken Elkington'un (1998) "Üççü Kar Hanesi" ya da "Üçlü Bilanço Sistemi" olarak Türkçeleştirilmiş "Triple Bottom Line" anlayışına göre KSS, ekonomik, çevresel ve sosyal sorumlulukları içermektedir.

Şirketlerin KSS faaliyetlerinin ölçülmesi ise KSP kavramını ortaya çıkarmıştır. Daha açık bir ifadeyle, KSS sosyal sorumluluk faaliyetleri ile ilgilenirken, KSP bu faaliyetlerin çıktıları ile ilgilenir (Salazar vd., 2012: 176). KSS'nin tanımlanmasındaki çeşitliliğe benzer şekilde KSP'nin ölçülmesinde de farklı yöntemler mevcuttur. Literatürde mevcut çalışmalarda, bir şirketin sürdürebilirlik endeksinde yer alması (Lourenço vd., 2012), sürdürebilirlik raporlaması yayınlaması (Cardamone vd., 2012), yayınladığı sürdürülebilirlik raporlamasının uluslararası düzeyde belirlenmiş kriterler baz alınarak hazırlanmış olması (Miralles-Quiros vd., 2017) söz konusu şirketin yüksek bir KSP'ye sahip olduğuna dair göstergeler olarak kabul edilmiştir. Ancak bu göstergeler, şirketlerin KSP düzeylerinin birbirlerine kıyasla durumu hakkında fikir vermekte yetersiz kalmaktadır. Ayrıca, şirketlerin KSP düzeyleri KSS tanımlamasında da vurgulandığı üzere birden fazla boyutu içermekte ve yine sözü edilen bu göstergeler ile şirketlerin bu boyutlardaki performanslarını ayrı ayrı değerlendirmek mümkün olmamaktadır.

Buradan hareketle bu çalışmada, şirketlerin KSP düzeylerini çevresel, sosyal ve yönetsel boyutlarda ayrı ayrı ele almaya ve sayısal olarak değerlendirmeye imkân tanıyan Thomson Reuters Datastream veri tabanının sunduğu şirket çevresel, sosyal ve yönetişim skorları kullanılmıştır. Bu skorlar vasıtası ile ölçülen KSP düzeylerinin hisse senedi fiyatlarına yansıma durumunu tespit etmek amacıyla Borsa İstanbul'da işlem gören şirketlerin 2009-2017 yılları arasına ait verileri panel veri yöntemleri ile analiz edilmiştir.

Yapılan analizler, şirket büyüklüğü, riski, karlılığı, sektörü gibi hisse senedi fiyatlarını etkileyebilecek faktörler kontrol altında tutulduğunda dahi genel KSP düzeyleri yüksek olan firmaların hisse senedi fiyatlarının da yüksek olduğunu göstermiştir. KSP düzeyi çevresel, sosyal ve yönetişim boyutları açısından ayrı ayrı değerlendirildiğinde sosyal ve yönetişim performansının piyasa değeri ile pozitif ve anlamlı bir ilişkiye sahip olduğu öte yandan çevresel performans ile piyasa değeri arasında anlamlı bir ilişki olmadığı görülmüştür.

$\mathrm{Bu}$ çalışma, gelişmekte olan bir ülke borsasında şirketlerin KSP düzeylerinin yatırımcı açısından önemine işaret etmekte gerek firmaları KSP düzeylerini artırma konusunda gerekse düzenleyici otoriteleri şirketlerin KSP düzeylerini artırmaya yönelik girişimleri hususunda teşvik etmektedir. 
Çalışmanın bundan sonraki bölümü şu şekilde düzenlenmiştir: Konuya ilişkin literatür taraması ikinci bölümde yer almaktadır. Üçüncü bölümde araştırma metodolojisi örneklem, veri, araştırma modeli ve değişkenleri içerecek şekilde detaylı bir şekilde açıklanmıştır. Analiz sonuçları dördüncü bölümde sunulmuş ve yorumlanmıştır. Nihai olarak sonuç bölümünde araştırma bulgularına dayanarak ulaşılan sonuçlar özetlenmiş, öneriler sunulmuş ve çalışmanın kısıtlarına yer verilmiştir.

\section{LITTERATÜR}

Şirketlerin KSP düzeyleri ile finansal performansları arasındaki ilişki bugüne kadar pek çok araştırmaya konu olmuştur. Bu araştırmalarda gerek KSP düzeyini gerekse finansal performansı tespit etmek için birbirinden farklı ölçütler kullanılmıştır. Finansal performansı ölçmek için kullanılan değişkenleri temelde muhasebe esaslı ve piyasa esaslı ölçütler olarak sınıflandırmak mümkündür. Aktif karlılılığı, özsermaye karlılığı gibi muhasebe esaslı ölçütler, sadece geçmiş performansı yansıttıkları, yönetici manipülasyonuna açık oldukları ve şirketin ileriye dönük, uzun vadeli performansını ve paydaşlar için ortaya çıkardığı katma değeri temsil etmedikleri konusunda eleştirilmektedir (Hillman ve Keim, 2001: 129). Ayrıca, finansal performans ölçütü olarak muhasebe esaslı ölçütler kullanan araştırmaların bulgularını, piyasa esaslı ölçütler kullanan araştırmaların bulguları ile kıyaslamak çok sağlıklı olmayacağından bu bölümde KSP düzeyi ile finansal performans arasındaki ilişkiyi konu edinen çalışmalardan finansal performansı ölçmek için piyasa esaslı ölçütler kullananlardan örnekler sunulmuştur.

Gelişmiş ülke piyasalarında, şirketlerin KSP düzeylerinin ya da KSS açıklamalarının şirketin piyasa değerine etkisini araştıran akademik çalışmalarda birbirinden farklı bulgular söz konusudur. KSP düzeyini belirlemek için Dow Jones Sürdürülebilirlik Endeksi’ne üyeliği esas alan Lourenço vd. (2012), KSP düzeyi ile piyasa değeri arasında güçlü bir ilişki tespit etmiş ve endekste yer almayan büyük ve karlı firmalara piyasanın olumsuz tepki verdiğini ortaya koymuştur. Benzer şekilde Dow Jones Sürdürülebilirlik Endeksi'ne üyeliği, KSP için temsili değişken olarak kullanan Arraiano (2020), endekste yer alan Avrupa bankalarının daha yüksek piyasa değerlerine sahip olduklarını tespit etmiştir. Yine Avrupa banka sektörünü ele alan bir başka çalışma, KSP'yi Thomson Reuters veritabanından elde ettikleri performans skorları ile ölçmüş ve KSP'yi oluşturan alt boyutlar için birbirinden farklı sonuçlara ulaşmıştır. Şirketlerin KSP'nin sosyal boyutunda gösterdikleri performans, muhasebe esaslı finansal performans ölçütleri ile pozitif ilişkili iken, piyasa esaslı finansal performansın KSP'nin sadece ekonomik boyutu ile ilişkili olduğu görülmüştür. Öte yandan yönetişim ve çevresel performans ile bankaların finansal performansları arasında (çevresel performans ve varlık karlılığı arasındaki ilişki hariç) anlamlı bir ilişki bulunamamıştır (Bussoli vd., 2019: 138). İtalya borsasında işlem gören şirketlerden oluşan bir örneklemi ele alan bir diğer çalışmada, şirketlerin çevresel, sosyal ve yönetişim performansları ile anormal getiri ile ölçülen finansal performansları arasında anlamlı bir ilişki bulunamamıştır (Landi ve Sciarelli, 2019: 24).

Gelişmekte olan piyasalarda gerçekleştirilen KSP ve finansal performans ilişkisini araştıran çalışmaların da, örneklemi gelişmiş ülke piyasalarından oluşan çalışmalara benzer şekilde birbirinden farklı bulgulara sahip olduğunu söylemek mümkündür. Hem muhasebe hem de piyasa esaslı finansal performans ölçütü kullanan Jha ve Rangarajan'ın (2020), S\&P BSE 500 endeksinde işlem gören beş yüz Hintli firmadan oluşan örneklem üzerinde yaptıkları 
analizler, muhasebe esaslı finansal performans ile KSP arasında anlamlı bir ilişki olmadığını, öte yandan piyasa esaslı finansal performans ile KSP arasında anlamlı ve negatif bir ilişki olduğunu göstermiştir. Ali, Hameedi ve Almagtome (2019), Irak borsasındaki şirketlerin Küresel Raporlama Girişimi (Global Reporting Inititative - GRI) göstergelerini içeren bir sürdürülebilirlik raporlaması yapıyor olmalarının yatırımcı kararlarında bir etkisi olmadığını ortaya koymuştur. Kim, Park ve Lee (2018) ise, Kore borsasında işlem gören şirketlerin KSS açıklamalarının, bu şirketlerin Tobin's Q oranı ile ölçülen finansal performanslarını pozitif etkilediğini ve bu pozitif etkinin dağınık sermaye yapısına sahip şirketlerde daha belirgin olduğunu göstermiştir.

Gelişmekte olan ülke olarak sınıflandırılan Türkiye'de de KSP ve finansal performans ilişkisi akademik çalışmalara konu olmuştur. Bu çalışmalardan Düzer ve Önce'nin (2018) çalışması Borsa Istanbul'da (BIST) işlem gören otuz şirket için hem muhasebe esaslı hem de piyasa esaslı finansal performans göstergelerinin KSP düzeyi ile ilişkisini araştırmıştır. KSP düzeyini ekonomik, çevresel ve sosyal boyutlarıyla ayrı ayrı elen alan bu çalışmada, şirketlerin bu boyutlardaki başarı düzeyini tespit etmek için yazarlar, şirketlerin sürdürülebilirlik raporlarındaki açıklamalarını GRI raporlama göstergelerini esas alarak değerlendirmişlerdir. Çalışma sonucunda muhasebe esaslı finansal performans göstergeleri ile şirketlerin çevresel ve sosyal performansları arasında anlamlı ve pozitif bir ilişki tespit edilmiştir. Öte yandan şirketlerin piyasa esaslı göstergelerle ölçülen finansal performansları üzerinde KSP'yi oluşturan boyutların hiçbirinin anlamlı bir etkiye sahip olmadığ görülmüştür. Tanç (2019), BIST 100 endeksindeki firmaların fiyat/kazanç oranları ile sürdürülebilirlik faaliyetleri arasında anlamlı bir ilişki olmadığını ortaya koymuştur. $\mathrm{Bu}$ çalışmada, sürdürülebilirlik faaliyetleri, şirketlerin sürdürülebilirlik raporlaması yapıp yapmamalarına bağlı olarak değerlendirilmiştir. Borsa İstanbul'da işlem gören şirketleri örneklem olarak ele alan bir başka çalışmada, BIST Sürdürülebilirlik Endeksi'nde yer almanın piyasa esaslı bir finansal performans ölçütü olan Tobin's Q üzerinde anlamlı bir etkisi olmadığı tespit edilmiştir (Gürünlü, 2019). Yılmaz, Aksoy ve Tatoğlu (2020), BIST sürdürülebilirlik endeksine dahil edilmenin ya da endeksten çıkarılmanın şirketlerin hisse senedi getirileri ve sistematik riskleri üzerinde anlamlı bir etkisi olmadığını ortaya koymuştur.

Buraya kadar bahsi geçen literatür 1şı̆̆ında, şirketlerin KSP düzeyleri ya da KSS açıklamaları ile finansal performansları arasındaki ilişkiyi araştıran akademik çalışmalarda tek ve ortak bir bulgu olmadığını söylemek mümkündür. Çalışmaların bulguları arasındaki bu tutarsızlık, KSP ve finansal performans ölçümü için farklı değişkenlerin kullanılmasına, analiz yöntemlerinin çeşitliliğine, kültürel faktörler, hukukun üstünlüğü, yasal sistem gibi örneklem ülkesine özgü faktörlere ve örneklem dönemindeki farklılıklara bağlanmıştır (Brooks ve Oikonomou, 2018).

Buradan hareketle bu çalışmada, KSP düzeyi ile finansal performans arasındaki ilişkiyi araştırırken gerek kullanılan temsili değişkenler gerekse analiz yöntemi ulaşılan sonuçların güvenilirliğini artıracak şekilde tespit edilmiştir. Türkiye için yapılmış birçok çalışmada olduğu gibi KSP ölçümü için sürdürülebilirlik endeksinde yer alma ya da almama durumunu temsil eden ikili bir değişken yerine KSP'yi tüm boyutları ile ele almaya imkân tanıyan ve Thomson Reuters Datastream ASSET4 veri tabanından elde edilen skorlar kullanılmıştır. Bu skorlar sayesinde gerek genel KSP düzeyinin gerekse KSP'nin çevresel, sosyal ve yönetişim boyutlarının firma performansı üzerindeki etkisi ayrı ayrı analiz edilebilmiştir. Analizlerin 2009-2017 yılları arasındaki dokuz yıllık geniş bir dönemi 
kapsaması, sürdürülebilirlik konusunun öneminin firmalar ve yatırımcılar tarafından anlaşılmış olması ve firmaların bu konudaki performanslarına yatırımcı tepkisinin daha net ortaya çıkması noktasında avantaj sağlamaktadır. Son olarak verilerin analizinde kullanılan panel veri yöntemleri, sadece yatay kesit ya da sadece zaman serisi veri kullanarak kolayca tespit edilemeyecek etkileri ölçme ve tespit etme konusunda daha elverişli yöntemlerdir. Ayrıca yatay kesit birimlerin gözlemlenemeyen etkilerini kontrol altında tutma, çoklu bağıntı problemini azaltma gibi avantajlar sunmaktadır (Baltagi, 2005: 5-6).

\section{ARASTTIRMA METODOLOJISİ}

\section{1. Örneklem ve Veri}

$\mathrm{Bu}$ çalışmanın ana evrenini Borsa İstanbul'da işlem gören tüm şirketler oluşturmaktadır. $\mathrm{Bu}$ ana evren içerisinden araştırma modelinde kullanılacak verilerine eksiksiz olarak ulaşılabilen şirketler, araştırmanın örneklemini oluşturmuştur. Araştırma modeli için gerekli veriler iki farklı veri tabanından elde edilmiştir. Şirketlerin KSP skorları Thomson Reuters Datastream ASSET4 veri tabanından elde edilirken finansal verilere Datastream veri tabanından ulaşılmıştır. İlk aşamada bu iki veri seti şirket bazında eşleştirilmiş ve tek bir veri seti haline getirilmiştir. İkinci aşamada, bu veri setinden, araştırma modeli için gerekli verileri eksik olan firma-yıllar ile hisse başına defter değeri negatif olan firma-yıllar çıkarılmıştır. Bu şekilde ulaşılan nihai örneklem 201 firma-yıl içermekte ve dengesiz panel veri seti özelliği taşımaktadır.

Örneklemin sektör bazında sınıflandırması, Tablo 1'de sunulmuştur. Tablo 1'den de görüldügü üzere örneklem içerisinde en çok gözlemlenen sektörler sırasıyla, finans $(\% 26,37)$, tüketici hizmetleri $(\% 16,42)$, tüketim malları $(\% 14,93)$ ve endüstriyel ürünler $(\% 13,43)$ olup bu sektörlerde faaliyet gösteren şirketlere ait firma-yıllar örneklemin yaklaşık \%70'ini temsil etmektedir.

Tablo 1. Sektör Bazında Örneklem

\begin{tabular}{lll}
\hline & \multicolumn{2}{l}{ Firma-Yıl } \\
\cline { 2 - 3 } Sektör & Sayı & $\%$ \\
\hline Finans & 53 & 26,37 \\
Tüketici Hizmetleri & 33 & 16,42 \\
Tüketim Malları & 30 & 14,93 \\
Endüstriyel Ürünler & 27 & 13,43 \\
Ana Metal Sanayi & 17 & 8,46 \\
Telekomūnikasyon & 17 & 8,46 \\
Enerji & 17 & 8,46 \\
Gayrimenkul & 7 & 3,48 \\
\hline TOPLAM & $\mathbf{2 0 1}$ & $\mathbf{1 0 0}$ \\
\hline
\end{tabular}




\subsection{Araştırma Modeli ve Değişkenler}

$\mathrm{Bu}$ çalışmada, şirketlerin KSP düzeylerinin hisse senedi fiyatlarına yansımasını tespit edebilmek için literatürde sıklıkla kullanılan (Ertuğrul, 2020: 2032) Ohlson'ın (1995) fiyat modeli esas alınmıştır. Fiyat modeli, hisse başına defter değeri ve hisse başına karın hisse senedi fiyatı üzerine regresyonunu içermekte olup aşağıdaki eşitlikle gösterilmektedir:

$$
H_{F I Y A T_{i t+1}}=\beta_{0}+\beta_{1} H B D D_{i t}+\beta_{2} H B K_{i t}+a_{i}+u_{i t}
$$

Eşitlik (1) ile gösterilen bu modele, şirketlerin KSP düzeyini temsil eden değişkenler ile hisse senedi fiyatlarını etkileyebilecek kontrol değişkenleri eklenmek suretiyle oluşturulan araştırma modelleri aşağıdaki gibidir:

$$
\begin{aligned}
& \operatorname{HFIYAT}_{i t+1}=\beta_{0}+\beta_{1} H B D D_{i t}+\beta_{2} H B K_{i t}+\beta_{3} K S P_{i t}+\beta_{4} X_{i t}+a_{i}+u_{i t} \\
& H_{F I Y A T_{i t+1}}=\beta_{0}+\beta_{1} H B D D_{i t}+\beta_{2} H B K_{i t}+\beta_{3} C E V_{i t}+\beta_{4} X_{i t}+a_{i}+u_{i t} \\
& \operatorname{HFIYAT}_{i t+1}=\beta_{0}+\beta_{1} H B D D_{i t}+\beta_{2} H B K_{i t}+\beta_{3} \operatorname{SOS}_{i t}+\beta_{4} X_{i t}+a_{i}+u_{i t} \\
& \operatorname{HFIYAT}_{i t+1}=\beta_{0}+\beta_{1} H B D D_{i t}+\beta_{2} H B K_{i t}+\beta_{3} Y_{\text {ON }}+\beta_{4} X_{i t}+a_{i}+u_{i t}
\end{aligned}
$$

Eşitlik (2), (3), (4) ve (5)'te ortak olarak yer alan HFIYAT hisse senedi fiyatını, $H B D D$ hisse başına defter değerini, $H B K$ hisse başına karı, $X$ kontrol değişkenlerini, $\beta_{0}$ sabit terimi, $\left(a_{i}+u_{i t}\right)$ ise bileşik hata terimini, $i$ ve $t$ alt simgeleri ise sırasıyla her bir şirketi ve yılı temsil etmektedir. Tüm modellerde, gerek finansal göstergelerin gerekse kurumsal sosyal performans göstergelerinin piyasa fiyatlarına yansıma süreci göz önünde bulundurularak hisse senedi fiyatı olarak mali yıl kapanışından altı ay sonraki fiyatlar esas alınmıştır. Eşitlik (2)'deki KSP şirketin genel kurumsal sosyal performansını, Eşitlik (3)'teki CEV çevresel performansı, Eşitlik (4)'teki SOS sosyal performansı ve Eşitlik (5)'teki YON yönetişim performansinı ifade etmektedir.

Şirketlerin KSP düzeyleri ile hisse senedi fiyatları arasındaki ilişkiyi tespit etmek için Eşitlik (1)'deki Ohlson'ın (1995) fiyat modeline Eşitlik (2), (3), (4) ve (5)'te sırasıyla şirketin genel kurumsal sosyal performans skoru $(K S P)$, çevresel performans skoru (CEV), sosyal performans skoru (SOS) ve yönetişim performans skoru $(Y O N)$ eklenmiştir. Bu skorlar, Thomson Reuters ASSET4 veri tabanından elde edilmiştir. Genel kurumsal performans skoru, şirketin çevresel, sosyal ve yönetişim skorlarının ağırlıklı ortalaması ile hesaplanmaktadır. Çevresel performans skoru (CEV), şirketin kaynak kullanımı, emisyon ve çevresel inovasyon konularındaki performansının değerlendirilmesi sonucu hesaplanan bir skordur. Sosyal 
performans skoru (SOS), iş gücü, insan hakları, toplum ve ürün sorumluluğu olmak üzere dört kategori skorunun ağırlıklandırılmış ortalamasıdır. Son olarak yönetişim skoru (YON) ise yönetim, paydaşlar ve kurumsal sosyal sorumluluk skorları temelinde hesaplanan bir skordur (Refinitiv, 2020).

Eşitlik (2), (3), (4) ve (5)'te $X$ ile gösterilen kontrol değişkenleri, fiyat modeli kullanan akademik çalışmalar göz önünde bulundurularak belirlenmiştir. Araştırma modellerine dahil edilen kontrol değişkenleri; şirket büyüklügüunü temsil eden ve toplam varlıkların doğal logaritması ile hesaplanan AKTF değişkeni, finansal riski temsil eden ve toplam borçların toplam varlıklara oranı şeklinde hesaplanan $F K A L$ değişkeni ve şirket karlılığını temsil eden aktif karlılık oranı (AKTFKAR) değişkenidir. Bu kontrol değişkenlerinin yanı sıra tüm modellere yıl ve sektör etkisini sabit tutabilmek amacıyla her bir yılı ve sektörü temsil eden kukla değişkenler de eklenmiştir.

\section{BULGULAR VE TARTIŞMA}

\subsection{Tanımlayıcı İstatistikler}

Analizlere başlamadan önce araştırma modellerinde yer alan tüm finansal değişkenler, araştırma sonuçlarını yanıltmaması için aşırı değerlerin etkisinden arındırılmıştır. Veri setindeki aşırı değerlerin etkisini azaltmak için literatürde sıklıkla kullanılan "törpüleme (winsorize)" işlemi kullanılmıştır (Hillier vd., 2016: 248; Machokoto vd., 2020: 29; Onali vd., 2017: 461). Bu işlem, temelde aşırı değerlerin belirlenen bir sınır değere düşürülmesidir (Boudt, vd., 2020: 376). Bu işlemin en önemli avantajı, veri kaybına yol açmaması ve bir dağılımdaki en yüksek ya da en düşük değere sahip gözlemin içerdiği bilgiyi muhafaza ederken aşırı değerlerin bazı zararlı etkilerine karşı koruma sağlamasıdır (Reifman ve Keyton, 2010: 1637). Buradan hareketle, veri setindeki tüm finansal değişkenler (HFIYAT, HBDD, HBK, AKTF, FKAL, AKTFKAR) \%5-\%95 aralığında törpülenmiştir.

Tablo 2'de, araştırma modellerinde yer alan değişkenlerin gözlem sayısı, ortalama, standart sapma, minimum ve maksimum değerlerini içeren tanımlayıcı istatistikleri sunulmuştur. Tablodan da görüldüğü üzere, şirketlerin KSP düzeylerini temsil eden, KSP, $C E V$, SOS ve $Y O N$ değişkenlerine ait standart sapmalar oldukça yüksek değerlere sahiptir. Bu durum, Borsa Istanbul'da işlem gören şirketlerin KSP düzeyleri açısından heterojen bir grup olduğu daha açık bir ifadeyle şirketlerin KSP düzeyleri arasındaki farkın yüksek olduğu anlamına gelmektedir. Zira söz konusu değişkenlerin minimum ve maksimum değerleri de örneklemde KSP düzeyi çok düşük ve çok yüksek gözlemlerin olduğunu doğrulamaktadır. 
Tablo 2. Tanımlayıcı İstatistikler

\begin{tabular}{lccccc}
\hline DEĞIȘKEN & Sayı & Ortalama & Standard Sapma & Minimum & Maksimum \\
\hline HFIYAT & 201 & 13,21 & 11,52 & 2,14 & 42,96 \\
HBDD & 201 & 16,08 & 4,32 & 1,34 & 16,93 \\
$H B K$ & 201 & 0,99 & 0,86 & 0,13 & 3,34 \\
KSP & 201 & 54,04 & 16,59 & 14,06 & 88,98 \\
CEV & 201 & 54,38 & 24,45 & 6,46 & 98,05 \\
SOS & 201 & 56,20 & 18,57 & 15,62 & 93,35 \\
YON & 201 & 51,14 & 19,12 & 8,22 & 90,53 \\
AKTF & 201 & 16,94 & 1,36 & 14,85 & 19,30 \\
FKAL & 201 & 0,64 & 0,19 & 0,32 & 0,90 \\
AKTFKAR & 201 & 7,22 & 4,99 & 0,99 & 17,47 \\
\hline
\end{tabular}

Notlar: HFIYAT mali yıl kapanışından 6 ay sonraki hisse senedi fiyatını, HBDD hisse başına defter değerini, HBK hisse başına karı, KSP kurumsal sosyal performans skorunu, CEV çevresel performans skorunu, SOS sosyal performans skorunu, $Y O N$ yönetişim performans skorunu, $A K T F$ toplam varlıkların doğal logaritmasını, $F K A L$ toplam borçların toplam varlıklara oranını, AKTFKAR aktif karlılık oranını temsil etmektedir.

Tablo 3, araştırma modellerinde yer alan değişkenlerin ikili korelasyonlarını göstermektedir. Tabloda yer alan genel kurumsal sosyal performans skorunu temsil eden KSP değişkeninin, çevresel performans skorunu temsil eden $C E V$ ve sosyal performans skorunu temsil eden SOS değişkenleri ile korelasyonunun \%80'in üzerinde olduğu görülmektedir. Söz konusu değişkenler dışında diğer değişkenler için ikili korelasyonlar \%80'in altındadır. KSP düzeyini temsil eden $K S P, C E V$, SOS ve GOV değişkenleri tek bir modelde aynı anda kullanılmadığından, araştırma modellerinin çoklu bağıntı probleminden etkilenmediğini söylemek mümkündür. Çoklu bağıntı probleminin tespitinde kullanılan bir diğer ölçüt ise varyans büyütme faktörüdür (variance inflation factor - VIF). Havuzlanmış en küçük kareler yöntemi ile tahmin edilen regresyon modelinden sonra hesaplanan VIF değerleri araştırma modellerinde çoklu bağıntı problemi olmadığını doğrulamaktadır. 
Tablo 3. Pearson Korelasyon Tablosu

\begin{tabular}{|c|c|c|c|c|c|c|c|c|c|c|}
\hline Değişken & HFIYAT & $H B D D$ & $H B K$ & $K S P$ & $C E V$ & SOS & YON & $A K T F$ & FKAL & AKTFKAR \\
\hline HFIYAT & 1 & & & & & & & & & \\
\hline$H B D D$ & $0,6529 * * *$ & 1 & & & & & & & & \\
\hline HBK & $0,6944 * * *$ & $0,6944 * * *$ & 1 & & & & & & & \\
\hline KSP & $0,4225 * * *$ & $0,4820 * * *$ & $0,3331^{* * *}$ & 1 & & & & & & \\
\hline CEV & $0,3929 * * *$ & $0,5041 * * *$ & $0,3931 * * *$ & $0,8883 * * *$ & 1 & & & & & \\
\hline SOS & $0,2865 * * *$ & $0,4868 * * *$ & $0,2869 * * *$ & $0,8316^{* * *}$ & $0,6671^{* * *}$ & 1 & & & & \\
\hline YON & $0,3181 * * *$ & $0,1027 * * *$ & 0,0631 & $0,6389 * * *$ & $0,3480 * * *$ & $0,2847 * * *$ & 1 & & & \\
\hline$A K T F$ & $-0,3766^{* * *}$ & $0,1662 * * *$ & $-0,0604$ & $0,2176 * * *$ & $0,2287 * * *$ & $0,4140 * * *$ & $-0,1750 * *$ & 1 & & \\
\hline$F K A L$ & $-0,1217 *$ & 0,0433 & 0,0549 & $0,2042 * * *$ & $0,2224 * * *$ & $0,3192 * * *$ & $-0,0967$ & $0,6426 * * *$ & 1 & \\
\hline$A K T F K A R$ & $0,3823 * * *$ & $-0,0862^{* *}$ & $0,3638 * * *$ & $-0,1829 * * *$ & $-0,1425^{* *}$ & $-0,3466^{* * *}$ & 0,0746 & $-0,7146^{* * *}$ & $-0,5572 * * *$ & 1 \\
\hline
\end{tabular}

Notlar: HFIYAT mali yıl kapanışından 6 ay sonraki hisse senedi fiyatını, HBDD hisse başına defter değerini, HBK hisse başına karı, KSP kurumsal sosyal performans skorunu, CEV çevresel performans skorunu, SOS sosyal performans skorunu, YON yönetişim performans skorunu, AKTF toplam varlıkların doğal logaritmasını, FKAL toplam borçların toplam varlıklara oranını, AKTFKAR aktif karlılık oranını temsil etmektedir. *, **,*** sırasıyla p<0,01, 0,05, 0,10 anlamlılık düzeylerine işaret etmektedir. 


\subsection{Regresyon Bulguları ve Tartışma}

Şirketlerin KSP düzeylerinin hisse senedi fiyatları ile ilişkisini tespit etmek amacıyla oluşturulan "Eşitlik (2), (3), (4) ve (5)"'in tahmini için en uygun yöntemi belirlemek amaciyla sırasıyla havuzlanmış sıradan en küçük kareler, tesadüfi etkiler ve sabit etkiler tahmincileri kullanılmıştır. Havuzlanmış en küçük kareler ve tesadüfi etkiler tahmincileri arasında karar vermek için Breusch-Pagan LM testi kullanılmıştır. Sıfır hipotezi birimler arasındaki varyansın " 0 " olduğu yönünde olan bu test sonucunda anlamlı bir test istatistiği elde edilmiştir. Bu durum Breusch-Pagan LM testinin sifir hipotezinin reddedilmesine yani tesadüfi etkiler modelinin havuzlanmış ek küçük kareler modeline tercih edilmesine neden olmuştur. Tesadüfi etkiler ve sabit etkiler tahmincileri arasında karar vermek için ise Hausman testinden faydalanılmıştır. Hausman testinin sıfır hipotezi, "tesadüfi ve sabit etkiler tahmincilerinin katsayılarındaki fark sistematik değildir." şeklindedir. Araştırma modelleri için uygulanan Hausman testi sonucunda sıfır hipotezi reddedilememiş dolayısıyla "Eşitlik (2), (3), (4) ve (5)"'in tahmini için en uygun tahmincinin tesadüfi etkiler olduğu tespit edilmiştir.

Araştırma modellerinin tahmini için en uygun tahmincinin tesadüfi etkiler olduğunun belirlenmesinden sonra modeller, tesadüfi etkiler tahmincisi varsayımlarından sapmaları tespit etmek için test edilmiştir. Bu testler sonucunda tüm modellerde, değişen varyans, serisel korelasyon

ve yatay kesit bağımlılık sorunları tespit edilmiştir. Dolayısıyla tüm araştırma modelleri, tesadüfi etkiler tahmincisi ve değişen varyans, serisel korelasyon ve yatay kesit bağımlılık sorunlarına dirençli olan Driscoll ve Kraay (1998) standart hataları ile çalıştırılmış ve sonuçlar Tablo 4'te sunulmuştur.

Tablo 4'te, sırasıyla "Eşitlik (2), (3), (4) ve (5)" ile gösterilen regresyon modellerinin sonuçları yer almaktadır. Şirketlerin genel KSP düzeyleri ile piyasa değerleri arasındaki ilişkiyi test etmek amaciyla oluşturulan ilk modelin tesadüfi etkiler ile tahmin edilmesi sonucunda, KSP değişkeni için pozitif ve anlamlı bir katsayı elde edilmiştir. Bu durum şirketlerin genel KSP düzeylerinin hisse senedi fiyatları ile pozitif yönde ilişkili olduğunu göstermektedir. KSP'yi oluşturan alt boyutların şirketlerin piyasa değerine olan etkisini ölçen diğer üç modelin sonuçları, konuya ilişkin daha detaylı bilgi sunmaktadır. Zira ilk modelde genel KSP düzeyi ile piyasa değeri arasında tespit edilen pozitif ve anlamlı ilişkinin şirketlerin sosyal ve yönetişim performanslarından kaynaklandığı, çevresel performanslarının ise piyasa değerleri ile ilişkili olmadığı görülmektedir. Çevresel performansın diğer KSP boyutlarının aksine piyasa değeri ile ilişkili çıkmaması beklenmedik bir sonuç olarak görülebilir. Fakat, çalışma örnekleminde finansal firmalar \%26'lik bir oran ile en çok gözlemlenen firmalardır. Finansal firmaların çevresel performanslarının göz önünde olmaması beklenen bir sonuç olmakla beraber akademik çalışmaların bulguları ile de desteklenmektedir (Bussoli vd., 2019: 139; Vastola vd., 2017: 272).

Şirketlerin KSP düzeyleri ile finansal performansları arasındaki ilişkiyi araştıran literatürde mevcut diğer çalışmalarda birbirinden farklı sonuçlar elde edildiğinden bu çalışmada ulaşılan pozitif yönlü ilişkiye dair bulguların, bazı çalışmalar ile uyumlu olduğunu (Arraiano, 2020; Kim vd., 2018; Jha ve Rangarajan, 2020) bazıları ile ise uyumsuz olduğunu (Bussoli vd., 2019; Landi ve Sciarelli, 2019; Gürünlü, 2019; Tanç, 2019) söylemek mümkündür. Fakat daha önce de vurgulandığı gibi gerek çalışmalarda kullanılan temsili 
değişkenler ve araştırma yöntemleri gerekse ele alınan örneklem, KSP - finansal performans ilişkisi için farklı sonuçlar elde edilmesinde önemli etkenler olduğundan bu hususlarda farklılık gösteren çalışmaların bulgularını kıyaslamak güvenilir bir sonuca ulaştırmayacaktır.

Tablo 4. Regresyon Sonuçları

\begin{tabular}{|c|c|c|c|c|}
\hline \multirow{2}{*}{$\begin{array}{l}\text { DEĞISSKENLER } \\
H B D D\end{array}$} & KSP & CEV & SOS & YON \\
\hline & 0,261 & 0,274 & 0,209 & 0,205 \\
\hline & $(0,173)$ & $(0,156)$ & $(0,175)$ & $(0,151)$ \\
\hline \multirow[t]{2}{*}{$H B K$} & $6,011^{* * *}$ & $6,354 * * *$ & $6,071^{* * *}$ & $6,345^{* * *}$ \\
\hline & $(1,353)$ & $(1,496)$ & $(1,542)$ & $(1,346)$ \\
\hline \multirow[t]{2}{*}{ KSP } & $0,091^{* *}$ & & & \\
\hline & $(0,028)$ & & & \\
\hline \multirow[t]{2}{*}{$C E V$} & & 0,035 & & \\
\hline & & $(0,022)$ & & \\
\hline \multirow[t]{2}{*}{ SOS } & & & $0,067^{* *}$ & \\
\hline & & & $(0,023)$ & \\
\hline \multirow[t]{2}{*}{ YON } & & & & $0,037 * *$ \\
\hline & & & & $(0,015)$ \\
\hline \multirow{2}{*}{$A K T F$} & - & - & $-4,032 * *$ & $-3,372 * *$ \\
\hline & $\begin{array}{l}3,935 * * * \\
(0,960)\end{array}$ & $\begin{array}{l}4,087 * * * \\
(0,933)\end{array}$ & $(1,292)$ & $(1,070)$ \\
\hline \multirow[t]{2}{*}{ FKAL } & 1,970 & 1,345 & 1,539 & 3,414 \\
\hline & $(2,835)$ & $(2,150)$ & $(3,160)$ & $(2,865)$ \\
\hline \multirow[t]{2}{*}{$A K T F K A R$} & $-0,157$ & $-0,193$ & $-0,157$ & $-0,190$ \\
\hline & $(0,170)$ & $(0,200)$ & $(0,183)$ & $(0,181)$ \\
\hline SEKTÖR & Evet & Evet & Evet & Evet \\
\hline YIL & Evet & Evet & Evet & Evet \\
\hline \multirow[t]{2}{*}{ Sabit } & $62,610 * *$ & $67,819 * *$ & $65,569 * *$ & $54,980 * *$ \\
\hline & $(13,271)$ & $(13,475)$ & $(18,844)$ & $(17,041)$ \\
\hline \multirow{3}{*}{$\begin{array}{l}\text { R2_O } \\
\text { Wald chi2 }\end{array}$} & 0,863 & 0,859 & 0,859 & 0,852 \\
\hline & $4540,34 *$ & $2964,58 *$ & $1875,95^{*}$ & 5710,91* \\
\hline & $* *$ & $* *$ & $* *$ & $* *$ \\
\hline
\end{tabular}

Notlar: HBDD hisse başına defter değerini, HBK hisse başına karı, KSP kurumsal sosyal performans skorunu, $C E V$ çevresel performans skorunu, SOS sosyal performans skorunu, YON yönetişim performans skorunu, AKTF toplam varlıkların doğal logaritmasını, FKAL toplam borçların toplam varlıklara oranını, AKTFKAR aktif karlılık oranını temsil etmektedir. Değişen varyans, serisel korelasyon ve yatay kesit bağımlılık sorunlarına dirençli olan Driscoll ve Kraay standart hataları parantez içinde verilmiştir. *,**,*** sırasıyla $\mathrm{p}<0,01,0,05,0,10$ anlamlılık düzeylerine işaret etmektedir. 


\section{SONUÇ}

$\mathrm{Bu}$ çalışmada şirketlerin KSP düzeyleri ile finansal performansları arasındaki ilişkiyi tespit etmek amaçlanmıştır. $\mathrm{Bu}$ doğrultuda, KSP düzeyini temsilen, Thomson Reuters Datastream ASSET4 veri tabanından elde edilen firmaların çevresel, sosyal ve yönetişim performans puanları ile tüm bu puanların ağırlıklandırılmış ortalaması ile hesaplanan genel KSP puanları kullanılmıştır. Finansal performans ise piyasa esaslı bir ölçüt olan hisse senedi fiyatları ile ölçülmüştür. Ampirik analizler, Borsa İstanbul'da işlem gören firmalara ait 201 firma-yılı kapsayan örneklem üzerinde panel veri analiz yöntemleri kullanılarak gerçekleştirilmiştir.

Araştırma sonuçları, şirketlerin genel KSP düzeyleri ile piyasa değerleri arasında pozitif ve anlamlı bir ilişki olduğunu ortaya koymuşstur. Bu pozitif ve anlamlı ilişki, KSP'nin sosyal ve yönetişim boyutu için yapılan analizlerle de desteklenmesine rağmen çevresel performans ile piyasa değeri arasında anlamlı bir ilişki bulunamamıştır. Araştırma örnekleminin büyük çoğunluğu finansal firmalardan oluştuğundan, bu durum finansal firmaların çevresel performanslarının yatırımcı açısından sosyal ve yönetişim performansı kadar önem taşımamasına bağlanmıştır.

$\mathrm{Bu}$ çalışma, gelişmekte olan bir piyasada, şirketlerin KSP düzeylerinin hisse senedi fiyatları ile ilişkisini ortaya koyarak firmalara KSP düzeylerini artırma ve düzenleyici otoritelere KSS faaliyetlerini teşvik edici düzenlemeler geliştirme konusunda yönlendirici bir nitelik taşımaktadır.

Çalışmanın bulguları değerlendirilirken örneklemin tek bir gelişmekte olan ülke piyasasını temsil ettiği dolayısıyla diğer gelişmekte olan ülkelere genelleştirilemeyeceği hususu göz önünde bulundurulmalıdır. Buradan hareketle bundan sonraki çalışmalarda, birden fazla ülkenin örneklem olarak ele alınması, ampirik analizlerin aynı temsili değişkenler ve aynı ekonometrik yöntemler kullanılarak gerçekleştirilmesi ülkeler arası farklılıkların daha güvenilir bir biçimde gözlemlenmesine katkı sağlayacaktır.

\section{KAYNAKLAR}

Ali, Maher Naji - Hameedi, Karrar Saleem - Almagtome, Akeel Hamza (2019), "Does Sustainability Reporting via Accounting Information System Influence Investment Decisions in Iraq", International Journal of Innovation, Creativity and Change, Volume 9, Issue 9, pp. 294-312.

Arraiano, Irene Guia (2020), Is There Value Creation in the Banks Listed in the Dow Jones Sustainability Index Europe?. D. Capaldi \& I. Schmidpeter (Eds.), Responsible Business in a Changing World, Springer, Cham, pp. 53-68.

Baltagi, Badi (2005), Econometric Analysis of Panel Data, John Wiley \& Sons Ltd, England.

Boudt, Kris - Todorov, Valetin - Wang, Wenjing (2020), "Robust Distribution-Based Winsorization in Composite Indicators Construction”, Social Indicators Research, Number 149, pp. 1-23. 
Brooks, Chris - Oikonomou, Ioannis (2018), “The Effects of Environmental, Social and Governance Disclosures and Performance on Firm Value: A Review of The Literature in Accounting And Finance”, British Accounting Review, Volume 50, Issue 1, pp. 115.

Bussoli, Candida - Conte, Danilo - Letorri, Graziana - Barone, Marco (2019), "Does It Pay to Be Sustainable? Evidence from European Banks”, International Journal of Business and Management, Volume 14, Issue 1, pp. 128-146.

Cardamone, Paola - Carnevale, Concetta - Giunta, Francesco (2012), "The Value Relevance of Social Reporting: Evidence From Listed Italian Companies”, Journal of Applied Accounting Research, Volume 13, Issue 3, pp. 255-269.

Carroll, Archie (1979), “A Three-Dimensional Conceptual Model of Corporate Performance”, Academy of Management Review, Volume 4, Issue 4, pp. 497-505.

Davis Keith - Blomstrom Robert (1975), Business and Society: Environment and Responsibility, McGraw-Hill, New York.

Driscoll, John - Kraay, Aart (1998), “Consistent Covariance Matrix Estimation with Spatially Dependent Panel Data”, Review of Economics and Statistics, Volume 80, Issue 4, pp. 549-560.

Düzer, Murat - Önce, Saime (2018), “Sürdürülebilirlik Performans Göstergelerine İlişkin Açıklamaların Finansal Performans Üzerine Etkisi: Bist’te Bir Uygulama”, Muhasebe ve Vergi Uygulamaları Dergisi, Cilt 11,Sayı 1, ss. 93-117.

Elkington John (1998), Cannibals with Forks: The Triple Bottom Line of 21st Century Business, New Society Publishers, Gabriola Island.

Ertuğrul, Melik (2020), "How Should the Value Relevance Research Employ Book Value of Equity?”, İşletme Araştırmaları Dergisi, Cilt 12, Sayı 2, ss. 2031-2039.

Gürünlü, Meltem (2019), "Sürdürülebilirlik ve Finansal Performans Arasındaki İlişki: BİST Şirketleri Üzerine Bir Araştırma”, Muhasebe ve Finansman Dergisi, Sayı 84, ss. 177 190.

Hillier, David - Hodgson, Allan - Ngole, Shaban (2016), "IFRS and Secrecy: Assessing Accounting Value Relevance Across Africa”, Journal of International Financial Management \& Accounting, Volume 27, Issue 3, pp. 237-268.

Hillman, Amy - Keim, Gerald (2001), "Shareholder Value, Stakeholder Management, And Social Issues: What's The Bottom Line?”, Strategic Management Journal, Volume 22, Issue 2, pp. 125-139.

Jha, Milind Kumar - Rangarajan, Krishnamachari (2020), “Analysis of Corporate Sustainability Performance and Corporate Financial Performance Causal Linkage in The Indian Context”, Asian Journal of Sustainability and Social Responsibility, Volume 5, Issue 1, pp. 1-30. 
Kim, Woo Sung - Park, Kunsu - Lee, Sang Hoon (2018), “Corporate Social Responsibility, Ownership Structure, and Firm Value: Evidence from Korea”, Sustainability, Volume 10, No 2497.

Landi, Giovanni - Sciarelli, Mauro (2019), “Towards a More Ethical Market: The Impact of ESG Rating on Corporate Financial Performance”, Social Responsibility Journal, Volume 15, Issue 1, pp. 11-27.

Lourenço, Isabel Costa - Branco, Manuel Castelo - Curto, José Dias - Eugénio, Teresa (2012), "How Does The Market Value Corporate Sustainability Performance?", Journal of Business Ethics, Volume 108, Issue 4, pp. 417-428.

Machokoto, Michael - Areneke, Geofry - Ibrahim, Boulis Maher (2020), "Rising Corporate Debt and Value Relevance of Supply-Side Factors in South Africa”, Journal of Business Research, Volume 109, March, pp. 26-37.

Miralles-Quiros, Maria del Mar - Miralles-Quiros, Jose Luis - \& Arraiano, Irene Guia (2017), "Are Firms That Contribute to Sustainable Development Valued By İnvestors?", Corporate Social Responsibility and Environmental Management, Volume 24,Issue 1, pp. 71-84.

Ohlson, James (1995), “Earnings, Book Values, and Dividends in Equity Valuation”, Contemporary Accounting Research, Volume 11, Issue 2, pp. 661-687.

Onali, Enrico - Ginesti, Gianluca - Vasilakis, Chrysovalantis (2017), "How Should We Estimate Value-Relevance Models? Insights From European Data”, The British Accounting Review, Volume 49, Issue 5, pp. 460-473.

Refinitiv (2020), "Environmental, Social and Governance (ESG) Scores from Refinitiv", https://www.refinitiv.com/content/dam/marketing/en_us/documents/methodology/esgscores-methodology.pdf (10.06.2020).

Reifman, Alan - Keyton, Kristina (2010), Winsorize. N. J. Salkind (Ed.), Encyclopedia of Research Design, Thousand Oaks, CA, Sage, pp. 1636 -1638

Salazar, José - Husted, Bryan - Biehl, Markus (2012), “Thoughts on The Evaluation of Corporate Social Performance Through Projects”, Journal of Business Ethics, Volume 105, Issue 2, pp. 175-186.

Tanç, Şükran Güngör (2019), "Kurumsal Sürdürülebilirlik Faaliyetlerinin Firma Değeri Üzerine Etkisi: Bist 100 Örneği”, İşletme Araştırmaları Dergisi, Cilt 11, Sayı 3, ss. 2076-2083.

Vastola, Vincenzo - Russo, Angeloantonio - Vurro, Clodia (2017), "Dealing with Cultural Differences in Environmental Management: Exploring the CEP-CFP Relationship", Ecological Economics, Volume 134, April, pp. 267-275. 
Yilmaz, Mustafa - Aksoy, Mine - Tatoglu, Ekrem (2020), “Does the Stock Market Value Inclusion in a Sustainability Index? Evidence from Borsa Istanbul”, Sustainability, Volume 12, Number 2, 483. 
